\title{
PENINGKATAN KREATIFITAS ANAK MELALUI KEGIATAN CHILDREN FUNDAY RPTRA AMANAH BUNDA KELURAHAN TANJUNG DUREN SELATAN
}

\author{
Ferdinand Fassa ${ }^{1}$, Sani Heryanto ${ }^{2}$, Andre Feliks Setiawan ${ }^{3}$ \\ ${ }^{1}$ Universitas Agung Podomoro \\ ${ }^{2}$ Univerrsitas Agung Podomoro \\ ${ }^{3}$ Universitas Agung Podomoro
}

ferdinand.fassa@podomorouniversity.ac.id, sani.heryanto@podomorouniversity.ac.id, andre.feliks@ podomoro.ac.id

\begin{abstract}
Abstrak
Kemaujuan teknologi terkadang dimanfaatkan untuk kegiatan yang kurang bermanfaat oleh masyarat secara umum dan anak-anak secara khusus. Penggunaan teknologi dapat memberikan dampak negatif terhadap anakanak jika tidak diawasi dengan baik, salah satunya adalah bermain game maupun menonton youtube di gadget tanpa pendampingan orang tua. Kegiatan tersebut berdampak kepada kurangnya olah tubuh da waktu beraktifitas anak-anak dengan lingkungannya sehingga dapat menurunkan daya kreatifitas maupun disiplin anak. Untuk meningkatan kreatifitas anak-anak maka diadakan kegiatan Children Fun Day (ChiFuDay) yang bertujuan untuk meningkatkan kreatifitas Anak-anak dan menumbuhkan sikap disiplin serta tanggung jawab anak-anak. Metode kegiatan ini dengan cara mengadakan lomba-lomba dan kegiatan yang menarik bagi anak-anak RPTRA dalam upaya untuk memberikan sikap sikap positif dengan cara yang menarik sehingga anak-anak tertarik dan juga menyerap nilai-nilai kepemimpinan dan kerjasama yang ada pada permainan/lomba/kegiatan yang ada. Adapun beberapa lomba yang akan diselenggarakan pada acara "ChiFuDay" yaitu: Tebak Gambar, Kuda Bisik, Estafek Sarung, Timang-timang dan Menyebrangi lautan. Kegiatan ChiFuDay dilaksanakan di wilayah RPTRA Amanah Bunda Tanjung Duren Selatan, yang mana wilayah ini tidak jauh dari lingkungan Universitas Agung Podomoro. Hasil akhir dari pelaksanakan kegiatan ChiFuDay adalah anak-anak dapat bertumbuh kembang dengan lingkungan yang baik melalui kegiatan yang membangun kreatifitas mereka.
\end{abstract}

Kata Kunci: Children Fun Day, Kreatifitas anak, RPTRA Amanah Bunda

\section{PENDAHULUAN}

Saat ini teknologi dan media sosial merupakan bagian yang dapat dipisahkan lagi dalam kehidupan masyarakat kota. Pengaruh media teknologi dan media sosial dapat berdampak baik maupun dapat berdampak buruk bagi masyarakat pada umumnya dan anak-anak pada khususnya. Setiap hari banyak kejadian-kejadian yang tidak terindentifikasi dengan jelas di media sosial dan mempengaruhi masyarakat untuk melihat dan membuatnya percaya dengan apapun yang tersebar namun tidak dapat di pastikan 
keasliannya. Informasi seperti ini dapat membuat masyarakat menjadi mudah terhasut dan memecah kerukunan. Selain itu anak-anak adalah individu yang paling mudah terpengaruhi oleh hal-hal baru, melalui media sosial atau omongan-omongan orang mereka akan meresap hal tersebut dan mengangapnya sebagai sebuah kebenaran tanpa mencari tahu kebenarannya. Untuk itu, dibutuhkan sebuah pembelajaran bagi mereka agar tidak terpengaruh terlalu banyak dengan hal-hal yang tidak dapat di pastikan kebenarannya. Anak-anak juga harus di ajarkan untuk memiliki rasa ingin tahu dan tidak mudah percaya.

Teknologi seperti gadget, terkadang digunakan untuk hal-hal yang kurang bermanfaat seperti bermain game secara berlebihan. Akibat dari ini anak-anak kurang bergerak, dan sering kali hak mereka untuk berkreatifitas secara baik menjadi berkurang. Hal ini dapat mempengaruhi tumbuh kembangnya.

Tumbuh kembang pada anak-anak adalah perubahan dan peningkatan kemampuan secara bertahap, seperti kemampuan motorik, sensori, bahasa, dan sosial (Hockenberry \& Wilson, 2012). Pertumbuhan dan perkembangan otak yang optimal membutuhkan lingkungan yang dapat menstimulasi, nutrisi yang cukup, dan interaksi sosial yang diberikan dengan penuh perhatian (UNICEF, 2013).

Melihat kondisi yang ada kami sebagai masyarakat pendidikan merasa perlu untuk memberikan edukasi kepada masyarakat umum khususnya anak-anak tentang kreatifitas yang dapat meningkatkan tumbuh kembang anak. Salah satu cara edukasi yang menurut kami perlu adalah dengan melakukan kegiatan Children Funday di lingkungan sekitar Universitas, tepatnya di kawasan RPTRA atau Ruang Publik Terpadu Ramah Anak Amanah Bunda Tanjung Duren Selatan seperti terlihat pada gambar 1.

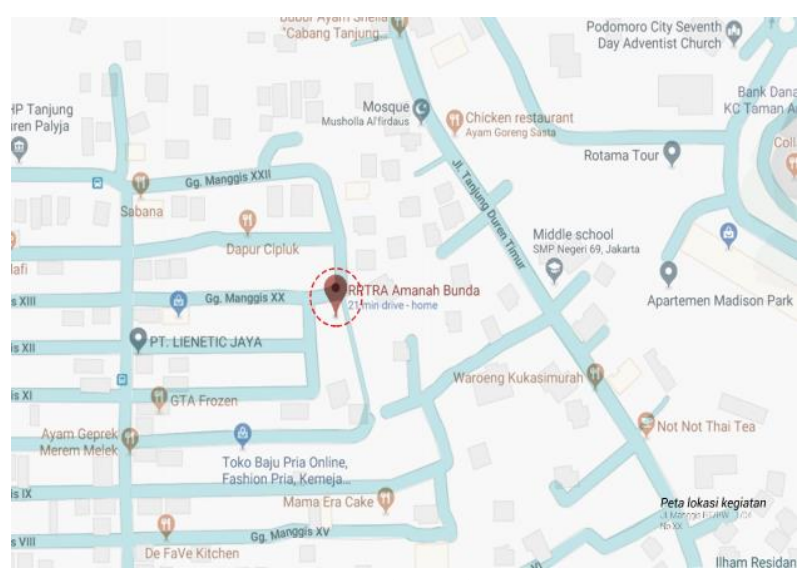

Gambar 1. Lokasi kegiatan PKM

RPTRA atau Ruang Publik Terpadu Ramah Anak merupakan ruang publik berupa ruang terbuka hijau yang menjadi sarana bagi masyarakat sekitar untuk melakukan kegiatan-kegiatan positif. Taman multifungsi ini tentunya dilengkapi dengan fasilitas yang memadai, dengan tujuan utama sebagai tempat untuk pendidikan anak. Anak-anak dapat berkumpul, bermain, dan belajar di tempat ini. Mereka dapat dengan leluasa mengeluarkan ide dan kreativitasnya masing-masing, bersosialisasi antar sesama, belajar bekerja sama.

Maka dari itu, karena RPTRA merupakan sarana utama bagi anak-anak untuk tumbuh berkembang, kami termotivasi untuk mengajak anak-anak di RPTRA Amanah Bunda yang berlokasi di Jakarta Barat untuk mempraktikan langsung bagaimana cara menumbuhkan kreatifitas anak sejak dini, sehingga diharapkan kegiatan tersebut dapat menjadi bekal dan diterapkan dalam kehidupan yang akan datang.

RPTRA Amanah Bunda adalah salah satu RPTRA yang terletak di Jakarta Barat. RPTRA ini selalu ramai oleh pengunjung dengan target yang selalu tercapai. Dimulai dari anak-anak, remaja, sampai orang dewasa berkumpul di RPTRA ini.

Setiap RPTRA mempunyai fungsi yang sama. Taman multifungsi dengan konsep ruang publik terbuka yang dibangun pada tahun 2017 ini mempunyai fungsi utama, yaitu sebagai tempat pendidikan dan tumbuh kembang anak. Fasilitas yang terdapat di RPTRA juga memenuhi hak dan kebutuhan anak, misal ruang aula serbaguna yang biasa dipakai untuk berkumpul dan belajar, serta 
melakukan kegiatan-kegiatan untuk melatih kreativitas. Kemudian ruang baca atau perpustakaan guna meningkatkan minat baca pada anak. Ruang PKK Mart, ruang laktasi, toilet umum, dan toilet difabel merupakan fasilitas pelengkap di RPTRA tersebut.

Tidak ada batasan usia bagi para pengunjung di RPTRA ini. RPTRA Amanah Bunda selalu dipenuhi anak-anak, rata-rata anak sekolah dasar sekitar usia 6-12 tahun. Kegiatan yang mereka lakukan saat ini adalah bermain gadget, bersama teman-teman lainnya dan belajar bersama. Dua kegiatan tersebut sangat baik dilakukan oleh anak-anak sejak dini karena bersosialisasi adalah tugas anak namun masih ada anak-anak yang bermain gadget tanpa control dari orang dewasa. Padahal, mereka butuh bermain untuk mengembangkan berbagai kemampuan, keterampilan, dan sikap. Pada masa kanak-kanak ini pula mereka perlu mengenal diri dan membentuk karakter pribadi mereka.

Dengan kondisi tersebut, maka kami mencoba untuk membuat program dalam rangka meningkatkan kreatifiatas dan mencoba agar dapat menurunkan kecanduan anak-anak terhadap gadget khususnya bermain games. Melalui kegiatan yang dapat menumbuhkan karakter yang baik, sikap kepemimpinan dan meningkatkan ketrampilan dan ketangkasan anak-anak. Tujuan dari kegiatan ini antara lain: 1) mengembangkan kreativitas anak sejak dini di lingkungan RPTRA Amanah Bunda, 2) menciptakan interaksi sosial pada anak sejak dini, 3) menumbuhkan semangat berkompetensi pada anak, 4) meningkatkan ketangkasan dan kekompakkan, 5) meningkatkan kepercayaan anak, 6) melatih sikap bertanggung jawab.

\section{METODE}

Dalam menjalankan program ini maka kami mengemas suatu kegiatan dalam bentuk acara yang dinamakan "Children Fun Day (ChiFuDay)". Acara ini memiliki tujuan untuk membangun sikap kepemimpinan, kreatif, dan juga untuk membangun kepercayaan anak sertra tanggung jawab sejak dini bagi anak anak. Alasam mengadakan acara "ChiFuDay" pada RPTRA adalah karena RPTRA merupakan tempat pendidikan dan tumbuh kembang anak. Fasilitas yang terdapat di RPTRA juga memenuhi hak dan kebutuhan anak, misal ruang aula serbaguna yang biasa dipakai untuk berkumpul dan belajar, serta melakukan kegiatan-kegiatan untuk melatih kreativitas. Selain itu, anak anak dari berbagai macam usia dan latar belakang datang bermain dan berkumpul bersama teman-teman mereka, sehingga akan mudah untuk mengumpulkan anak-anak dan mengajak mereka untuk melakukan sebuah kegiatan yang dimana bertujuan untuk membantu mengembangkan karakteristik positif untuk menghindari terjadinya penyebaran Hoax dan juga hilangnya sikap kepahlawanan dalam diri anakanak. Untuk alasan inilah, acara "ChiFuDay" diadakan pada salah satu RPTRA yaitu RPTRA Amanah Bunda

Acara "ChiFuDay" ini merupakan acara yang didalamnya terdapat beberapa lomba-lomba dan kegiatan yang menarik bagi anak-anak RPTRA dalam upaya untuk memberikan sikap sikap positif dengan cara yang menarik sehingga anak-anak tertarik dan juga menyerap nilai-nilai kepahlawanan yang ada pada permainan/lomba/kegiatan yang ada. Adapun berikut ini beberapa lomba yang akan diselenggarakan pada acara "ChiFuDay" yaitu: 1) Tebak gambar, 2) Kuda bisik, 3) Estafet Sarung, 4) Timang-Timang, 5) Menyeberangi Lautan, 6) Mozaic Pulau, 7) Fashion Show Koran.

Lomba-lomba yang diadakan ini memiliki nilainilai kepemimpinan, yaitu sikap yang berani, tangguh, rela berkorban, dan bertanggung jawab. Sifat kepemimpinan itulah yang menjadi dasar dimana seseorang dapat menjadi pemandu bagi dirinya masing-masing. Sebagai seorang pemimpin, tentunya harus dapat memandu dirinya sendiri dan orang lain dengan baik. Serangkaian keterampilan pun diperlukan untuk menjadi sosok yang kreatif dalam mengatur diri, mengatasi masalah, dan menambah pengetahuan serta ketangkasan dalam bertindak. Tujuan diadakan lomba-lomba ini untuk mengajarkan nilai-nilai tersebut adalah untuk memikat anak-anak dalam kegiatan yang menarik sehingga anak-anak merasa tidak terpaksa dan antusias mengikuti kegiatan lomba lomba yang ada. Kegiatan- kegiatan ini juga memiliki nilai nilai kerjasama dan kekompakan pada anak-anak dalam masing masing kelompok yang juga melatih kesabaran, pengertian dan juga semangat bekerja sama pada anak anak.

$$
\text { Ekonomi, Sosial dan Budaya }
$$


Pelaksanaan kegaitan sosialisasi ini memerlukan beberapa tahapan kegiatan seperti terlihat pada gambar 1 dibawah ini.

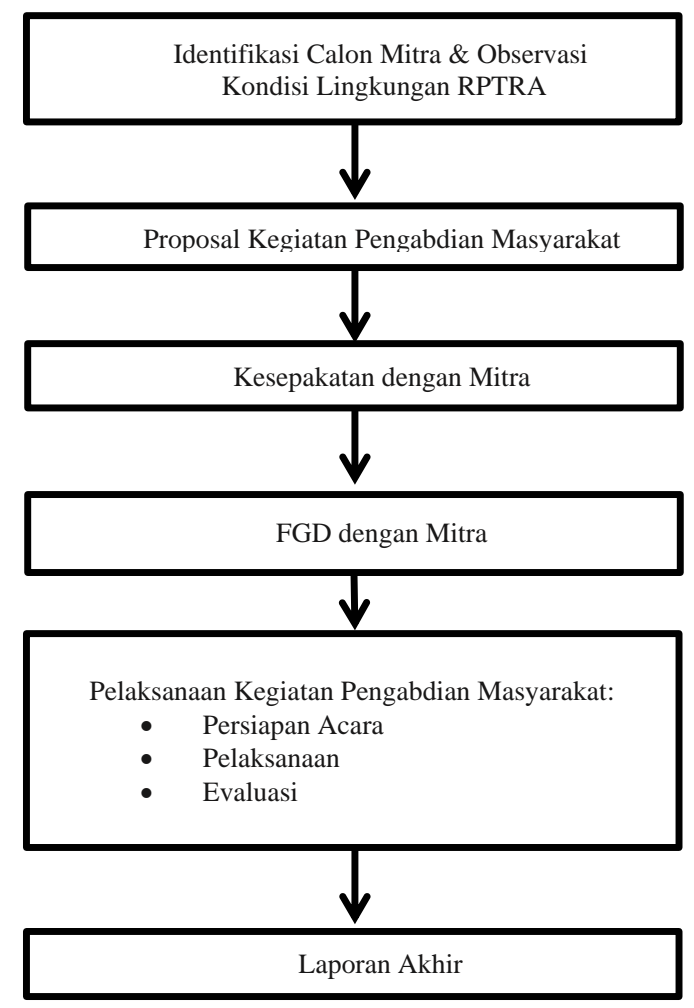

Gambar 2. Bagan Alir Kegiatan Sosialisasi

Berdasarkan gambar 2, tahapan pertama adalah: 1) Tim Pengabdian Kepada Masyarakat (PKM) mengunjungi RPTRA Amanah Bunda dan melakukan diskusi dengan pengelola perihal jumlah peserta dan bantuan dari pengelola RPTRA Amanah Bunda untuk mengundang para anak-anak disekitar RPTRA Amanah Bunda. Selain membahas jumlah peserta, kegiatan ini juga membahas tentang penentuan hari dan jam pelaksanaan acara sosialisasi. 2) Pembuatan surat izin atau persetujuan yang akan diberikan kepada kelurahan sebagai pengumuman adanya acara di RPTRA Amanah Bunda. 3) Pembuatan proposal acara. 4) Melakukan riset tentang kegiatan. 5) Membeli alat dan bahan. 6) Menghitung jumlah anggaran biaya. Dalam memulai kegiatan acara "ChiFuDay" ada beberapa tahapan yang akan dilaksanakan demi lancarnya acara. Tim membantu mengumpulkan peserta (anak-anak) ke aula, serta mengatur tempat duduk sehingga tercipta suasana yang kondusif. Kemudian pembawa acara mulai melaksanakan pembagian kelompok serta menjelaskan aturan dan jalannya acara. Sementara panitia memantau dan ikut mendengarkan. Saat proses ini pembacara acara dibantu dengan mentor kelompok menjelasakan beberapa aturan yaitu: peserta dibagi menjadi 5 kelompok yang terdiri dari 7-8 orang (jumlah dapat berubah tergantung dari banyak nya peserta yang hadir). Untuk pembagian nya berdasarkan perhitungan undi yang dipandu oleh pembawa acara (dimulai dari barisan paling depan sebelah kanan, kemudian berlanjut ke orang berikutnya) seperti terlihat pada gambar 3 dan 4 .

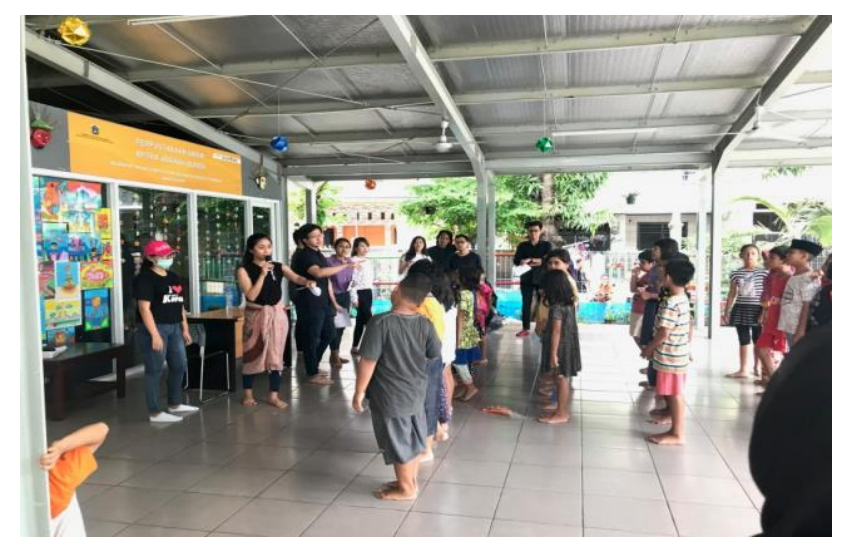

Gambar 3. Sesi Pembagian Kelompok

Setelah kelompok sudah terbagi, maka setiap peserta harus bergabung dengan teman kelompoknya. Kemudian ada 1 orang panitia yang bertugas menjadi fasilitator atau Pembina kelompok. Fasilitator harus membawa kertas dan pulpen untuk mencatat anggota kelompoknya. Fasilitator bertugas untuk mendampingi anggota kelompoknya dalam bermain games. Nama kelompok berdasarkan nama pahlawan.

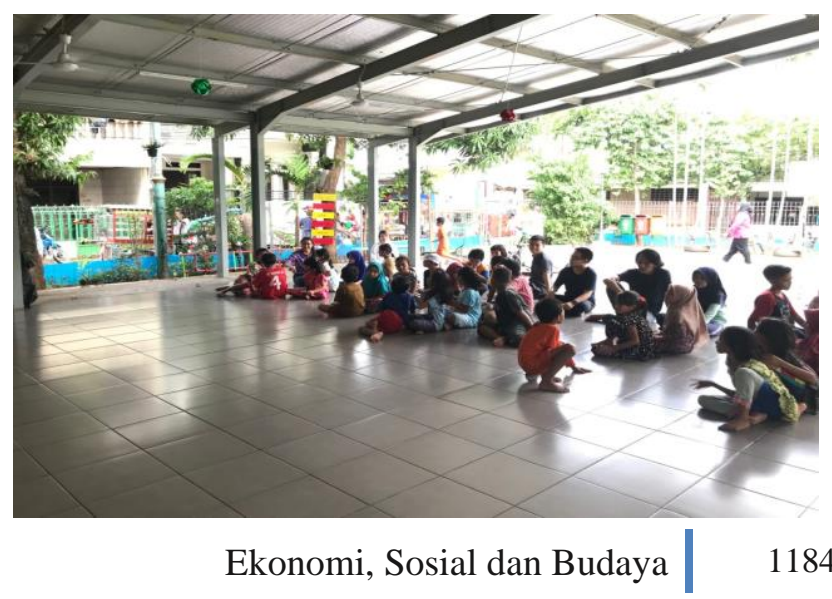




\section{Gambar 4. Sesi Pembagian Kelompok}

Ketika semua kelompok telah berkumpul (Gambar 3 \& 4), pembawa acara memberikan gambaran jalannya acara yang berupa seperti: cara permainan berupa pos. Dimana setiap pos memiliki permainan yang berbeda-beda. Selain itu tiap kelompok diminta untuk mempersiapkan yel-yel kelompok dan menampilkan didepan kelompok lainnya (gambar 5).

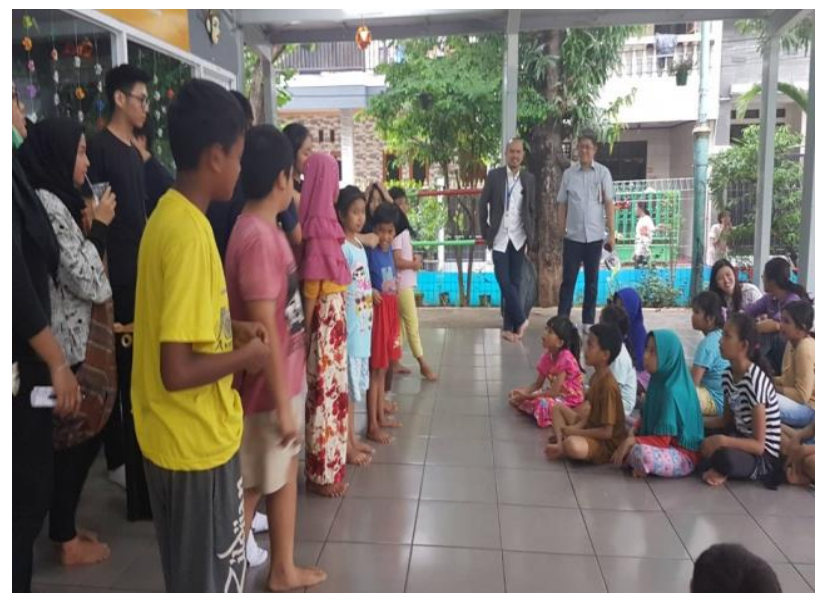

Gambar 5. Yel-Yel Kelompok

Untuk waktu permainannya adalah semua kelompok bermain dalam waktu yang bersamaan di masing-masing pos. Setiap pos terdapat 1 orang panitia sebagai penjaga pos. 1 pos hanya diberikan waktu 10-15 menit untuk melakukan permainan. 5 menit awal digunakan untuk memberikan instruksi. Untuk fasilitas barang yang disediakan harus dijaga dan dikembalikan seperti semula. Setiap kelompok akan mendapat pengurangan -5 point apabila melakukan pelanggaran yang di buat di dalam permainan. Juga melanggar peraturan selam acara. Pengurangan point akan berlanjut apabila masih terus melakukan pelanggaran. Adapun detail lomba per pos dijabarkan sebagai berikut:

Lomba I (Tebak gambar)

Alat dan bahan yang dibutuhkan: Kertas a4 dan spidol snowman. Dengan keterangan instruksi: Anggota kelompok membuat satu barusan. Kemudian orang yang paling belakang dibisikan tentang apa yang harus digambar. Kemudian orang yang paling belakang menunjukan gambar kepada orang yang berada didepannya tanpa berbicara. Dan begitu seterusnya sampai ke orang yang paling depan. Orang yang paling depan lah yang bertugas untuk menebak gambar tersebut. Setiap orang diberikan waktu 1 menit untuk menggambar. Gambar yang ditebak seputar buah, hewan, alat elektronik.

\section{Lomba II (Kuda bisik)}

Alat dan bahan yang dibutuhkan tidak ada. Dengan keterangan instruksi: Anggota kelompok membuat 2 barisan. 1 barisan akan menjadi sebagai orang yang memeragakan gaya, sedangkan 1 barisan lainnya akan menjadi orang yang menebak gaya yang diperagakan. Kelompok harus menebak gaya dengan benar. Aturan: Konten kalimat yang diberikan seputar kepahlawanan, Pendidikan serta hiburan.

Lomba III (Estafet sarung)

Alat dan bahan yang dibutuhkan: sarung. Dengan keterangan instruksi: Anggota kelompok membuat satu barisan secara menyamping(linear). Setiap orang merentangkan tangan sehingga ada sedikit jarak untuk bergerak dan juga bergandengan tangan. Kemudian panitia memberikan sarung yang kepada orang yang paling ujung. Setelah itu orang yang paling ujung memberikan sarung kepada orang sebelah nya tanpa melepas gandengan tangan. Begitu seterusnya sampai ke orang yang paling akhir dan memberikan nya kepada panitia. Aturan: tidak melepaskan gandengan tangan.

Lomba IV (Timang-timang)

Alat dan bahan yang dibutuhkan: kayu balsa. Dengan keterangan instruksi: Anggota kelompok membagi kelompok menjadi 2 barisan yang saling berhadapan satu dengan yang lainnya. Kemudian setiap orang menjulurkan jari kedepan. Sehingga saling bertemu setiap jari telunjuk nya. Setelah barisan sudah siap, panitia memberikan kayu basa diatas jari telunjuk para anggota. Setelah itu para anggota harus menurunkan balsa tersebut dari atas ke bawah lantai, tanpa jatuh dan tanpa melepaskan juluran jari telunjuk. Aturan: jari telunjuk tetap terhubung, kayu balsa tidak jatuh.

Lomba IV (Menyebrangi lautan)

Alat dan bahan yang dibutuhkan: kardus ukuran 60x40 cm ,2 lembar. Dengan keterangan instruksi: 
Panitia memberikan 2 potongan kardus. Dari garis start. Semua anggota kelompok harus berdiri diatas 1 lembar kardus. Setelah itu 1 potongan kardus sisanya digunakan untuk berjalan. Anggota kelompok berpindah dengan menggunakan potongan tersebut, dan begitu seterusnya sampai mencapai garis finish. Aturan: tidak menginjak lantai, harus berjalan menggunakan kardus.

Setelah melakukan games per pos. kemudian semua kelompok akan berkumpul ke aula untuk melakukan permainan yang lebih besar dan universal. Pembawa acara mengambil alih untuk mengumpulkan anak-anak ke dalam kelompoknya dan memberikan instruksi untuk permainan tersebut.

Permainan terdapat menjadi 2 sesi. Untuk sesi pertama ialah Mozaic pulau. dan yang kedua ialah fashion show koran. Semua kelompok harus berkumpul bersama dengan anggotanya. Sementara itu panitia memberikan alat dan bahan yang dibutuhkan.

\section{Mozaic Pulau}

Alat dan bahan yang dibutuhkan: kanvas, bijibijian, dan lem fox. Dengan keterangan instruksi: Setiap kelompok diberikan kanvas yang sudah ada gambaran dari panitia. Kemudian dengan bahan yang ada berupa biji-bijian. Para anggota harus menempel biji-bijian tersebut ke kanvas yang ada mengikuti pola yang ada.

\section{Fashion Show Koran}

Alat dan bahan yang dibutuhkan: gunting, 5 edisi koran, selotip. Dengan keterangan instruksi: Setiap kelompok diberikan 1 edisi koran, gunting, dan selotip. Kemudian koran tersebut harus dibuat untuk menjadi atribut pahlawan (senjata, topi, aksesoris dsb nya) dengan alat dan bahan yang disiapkan harus tercipta kreatifitas nya. Bebas dengan cara digunting, tempel, atau di lem. Setiap anggota mengirimkan 2 orang perwakilan untuk maju mempresentasikan dan melakukan fashion show.

\section{HASIL DAN PEMBAHASAN}

\section{Pelaksanaan}

Pelaksanaan berdasarkan pos yang telah ditetapkan, pada gambar 6 terlihat lomba menyebrangi lautan dari kelompok 1.

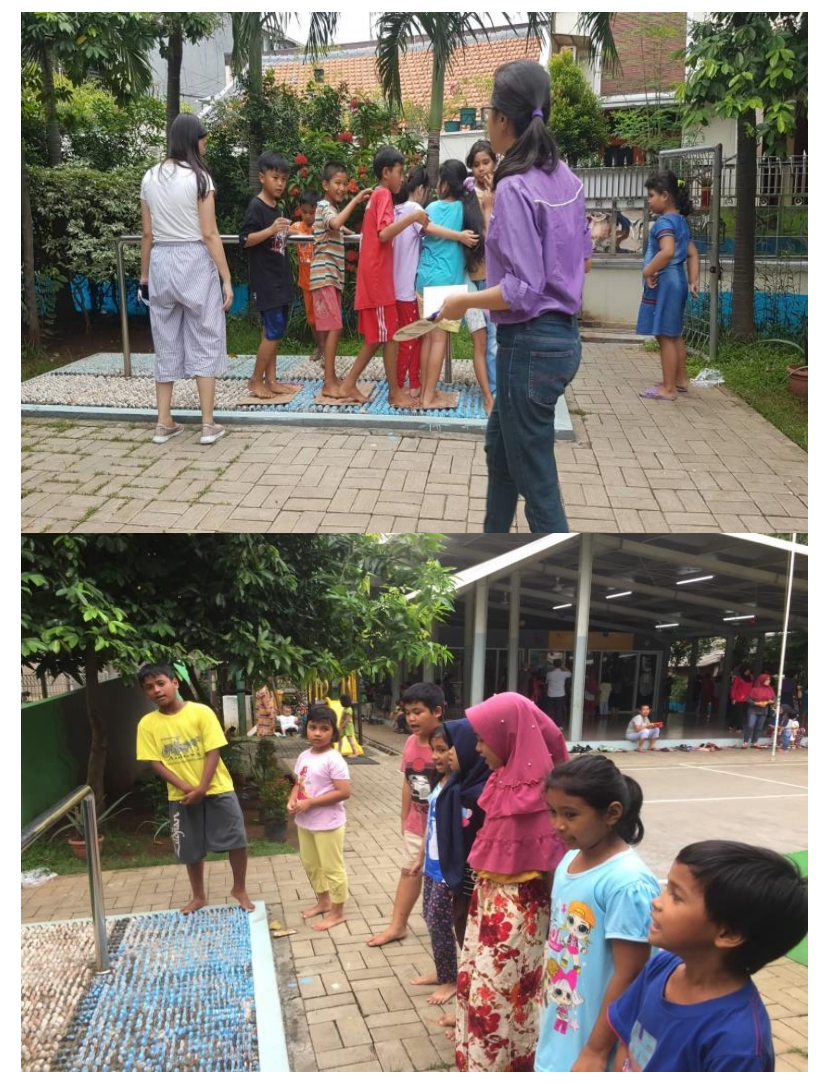

Gambar 6. lomba Menyebrangi Lautan

Sedangkan dikelompok lain terlihat pada gambar 7 melakukan permainan timang-timang.

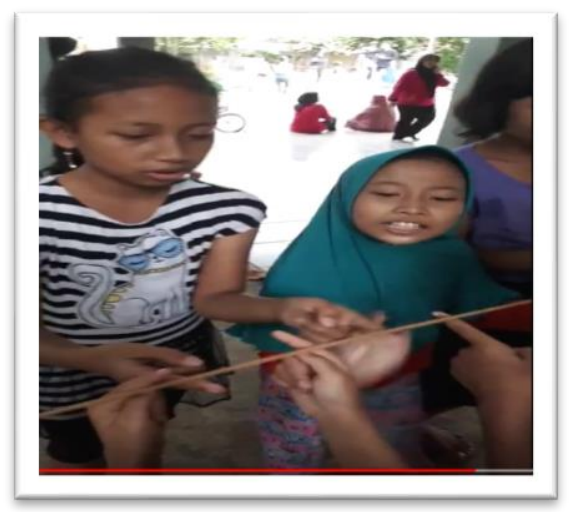

Ekonomi, Sosial dan Budaya 


\section{Gambar 7. Permainan Timang-Timang}

Pada pelaksanaan kegiatan ini, terdapat beberapa perubahan yang terjadi pada kegiatan "ChiFuDay" yang berlangsung pada 3 Mei 2019. Perubahan pertama yang terjadi adalah jam mulai berlangsungnya acara. Sebelumnya, kegiatan ini direncanakan akan dimulai pada pukul 14.45 WIB. Hal ini terjadi karena anak-anak yang belum berkumpul di RPTRA Amanah Bunda dan kurangnya komunikasi antar panitia dengan pihak RPTRA.

Kegiatan pertama yang dibuka oleh para MC adalah pembukaan dari MC, yang diikuti oleh panitia acara dan panitia RPTRA. Namun, karena adanya keterlambatan dari pihak panitia, maka kegiatan pertama yang dibuka oleh para MC adalah ice breaking guna mengumpulkan anak-anak di aula RPTRA Amanah Bunda. Rencana awal pembukan dan sambutan seharusnya dimulai pukul 14.45 namun realisasinya digeser menjadi pukul 15.15.

Terkait dengan anggaran terdapat beberapa perubahan anggaran dana. Rencana biaya yang dikeluarkan untuk acara ini adalah Rp1.000.000 (satu juta rupiah), namun pada pelaksanaannya menjadi Rp. 777.600, sehingga terdapat sisa dana dari jumlah rencana pengeluaran yang seharusnya, yaitu sebesar Rp222.400 (dua ratus dua puluh dua ribu rupiah enam ratus rupiah).

\section{Permasalahan dan Solusi saat acara}

Terdapat beberapa kendala selama acara, seperti: 1) Para peserta yang hadir tidak sesuai list yang sudah diberikan panitia RPTRA sebelumnya. 2) Para peserta yang tidak kondusif saat pembagian kelompok. 3) Beberapa peserta terlihat tidak disiplin selama kegiatan berlangsung. 4) Terdapat tiga peserta yang dikeluarkan dari kelompok karena tidak tertib selama mengikuti acara.

Sedangkan solusi yang dilakukan panitia: 1) Panitia tetap membagikan kelompok secara random agar adil dan sesuai dengan kesepakatan bersama. 2) Pembawa acara mengarahkan dengan tegas kepada para peserta. 3) Pembawa acara melakukan sanksi kepada para peserta yang tidak disiplin, yaitu dikeluarkan dari kelompok dan tidak diperbolehkan mengikuti acara kembali.

Setelah lomba selesai, maka dilanjutkan dengan sesi pembagian hadiah dan foto bersama (gambar 8 \& gambar 9).

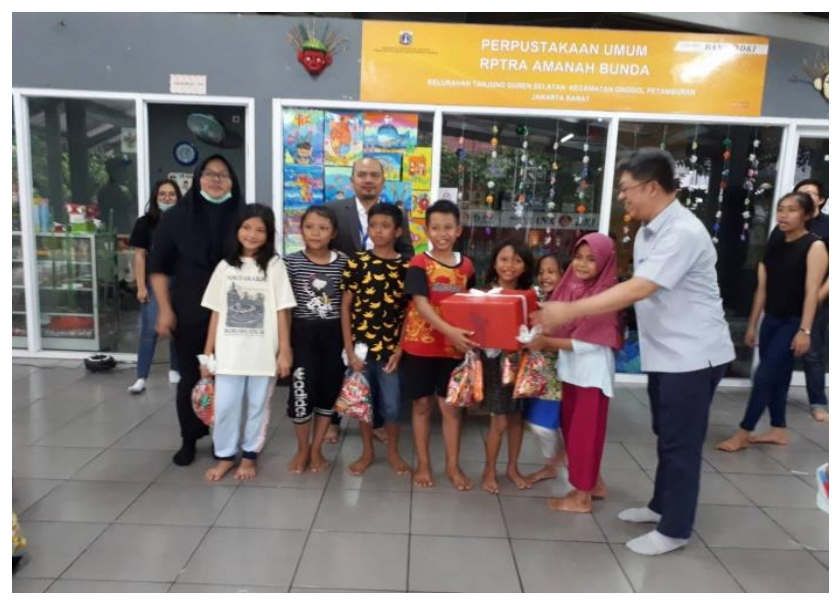

Gambar 8. Pembagian Hadiah

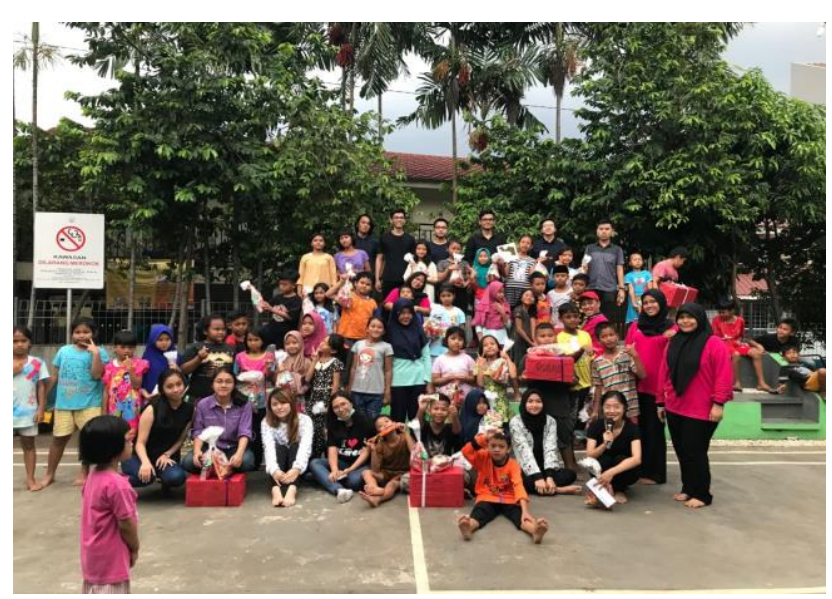

Gambar 9. Foto Bersama

\section{KESIMPULAN}

Berdasarkan hasil pelaksanaan dari kegiatan Pengabdian Masyarakat ini dapat diambil beberapa kesimpulan, yaitu: 1) Kegiatan permainan ini membuat anak-anak senang dan meningkatkan kreatifitas anak 2) Selain itu anak-anak berinteraksi 
dengan baik sehingga dari observasi terlihat kerjasama yang baik diantara kelompok. 3) Setelah selesai anak-anak diminta untuk ikut membersihkan area sehingga kegiatan ini dapat meningkatkan tanggung jawab anak-anak.

\section{UCAPAN TERIMAKASIH}

Dalam kegiatan pengabdian ini, TIM PKM mengucapkan terima kasih kepada Lurah Tanjung Duren Selatan, Pengelola dan masyarakat RPTRA Amanah Bunda, pengurus RPTRA di lingkungan kecamatan Petamburan Grogol, Lembaga Pengabdian Masyarakat Universitas Agung Podomoro, mahasiswa (Farahiyah Badzlina, Claudia A, Jeorges Rio, Virgiana Julia, Rio C) Kelas Manajemen Proyek Universitas Agung Podomoro yang telah berperan aktif dalam mensukseskan kegiatan ini.

\section{REFERENSI}

Dra. Nana Prasetyo, M. Si. (2011), Membangun Karakter Anak Usia Dini. Direktorat Pembinaan Pendidikan Anak Usia Dini Direktorat Jenderal Pendidikan Anak Usia Dini Nonformal dan Informal Kementerian Pendidikan Nasional Tahun 2011.

Hockenberry, M \& Wilson, D. (2012). Wong's Essentials of Pediatric Nursing (9th Ed.). St Louis: Elsevier Inc.

UNICEF. (2013). The formative years: UNICEF's work on measuring early childhood development. Diperoleh dari https://data.uni cef.org/resources/the-formative-years-unicef 